\title{
Mystery Manifested: Toward a Phenomenology of the Eucharist in Its Liturgical Context
}

\author{
Christina M. Gschwandtner \\ Department of Philosophy, Fordham University, Bronx, NY 10458, USA; gschwandtner@fordham.edu
}

Received: 15 April 2019; Accepted: 6 May 2019; Published: 9 May 2019

\begin{abstract}
This article explores three contemporary phenomenological analyses of the Eucharist by the French phenomenologists Jean-Luc Marion, Jean-Yves Lacoste, and Emmanuel Falque, arguing that their descriptions are too excessive and individual, failing to take into account the broader liturgical context for eucharistic experience. The second part of the discussion seeks to develop an alternate phenomenological account of eucharistic experience that takes Eucharist seriously as a corporeal and communal phenomenon that is encountered within a liturgical horizon and which requires a liturgical intentionality to be prepared for and directed toward it.
\end{abstract}

Keywords: Eucharist; liturgy; phenomenology; Jean-Luc Marion; Jean-Yves Lacoste; Emmanuel Falque

Philosophical reflection on the sacraments—especially the Eucharist-has a long history. Aquinas employs and alters Aristotelian categories of substance and accidents for his account of a eucharistic ontology; Descartes discusses the impact of new insights in physics on the epistemology of the Eucharist in several letters to Marin de Mersenne; Leibniz tries to reconcile Lutherans and Calvinists with a "monadic" interpretation of eucharistic substance; Hegel employs a natural philosophy of the living organism as an argument for a Lutheran interpretation of the Eucharist as sacramental reality (Alexandrescu 2007; Backus 2011; Fouke 1992; Finn 2015-2016). Such philosophical explications of the sacraments have been metaphysical, ontological, epistemological, physical or biological, even hermeneutic. Maybe the most recent and surely one of the most fruitful approaches is phenomenological. Several contemporary French philosophers have employed phenomenological tools derived from Edmund Husserl and Martin Heidegger in order to articulate a philosophical account of religious experience, in which analyses of the sacrament of the Eucharist play a prominent role.

What can phenomenology bring to our understanding of and encounter with the sacraments? Phenomenology is the study of our experience of phenomena, of their modes of manifestation and revelation, the ways in which we apprehend and experience them. Unlike approaches in the social sciences, phenomenology is not primarily concerned with empirical experience-how this or that person might experience a specific event at a particular moment-but rather with the broader structures of experience in order to ascertain what sort or kind of experience it is, its various modes of manifestation, and how it reveals something about the human condition. Early philosophical phenomenology often excluded any considerations of religious experience, which it deemed too esoteric or transcendent, in order to focus on issues of perception, imagination, or memory and the ways in which phenomena are experienced via temporality, spatiality, corporeality, affectivity, i.e., the very structures within and through which experience occurs. ${ }^{1}$ Increasingly, contemporary philosophers like Paul Ricoeur, Michel Henry, Jean-Luc Marion, Jean-Yves Lacoste, Jean-Louis Chrétien, Emmanuel Falque, and others,

1 This is true of "classical" philosophical phenomenologists like Husserl, Heidegger, Sartre, and Merleau-Ponty. Other thinkers, both philosophers like Scheler, Stein, and Walther or those in other fields like Otto, Eliade, Kristensen, and van der Leeuw, did draw on phenomenology for analyses of religious phenomena. See my brief survey of and introduction to these thinkers (Gschwandtner 2019), especially Part I. (Part II focuses on the French thinkers, some of whom are discussed in the present 
have suggested that a phenomenological approach might also be profitable for analyzing religious experience, faith, and the sacraments. References to the Eucharist in particular can be found in almost all of these thinkers.

This contribution will focus on three of the fullest phenomenological analyses of the Eucharist, that of Marion, Lacoste, and Falque, suggesting that each highlights some aspect of its phenomenality, how the phenomenon is given, how the phenomenon is received, and how it involves and illuminates a particular notion of corporeality. The essay will set forth and critically evaluate these proposals, showing that they are still too prone to consider the Eucharist in isolation from its liturgical and ritual context. For this reason, these analyses of the phenomenality of the Eucharist tend to describe it as a solitary and excessive phenomenon, disregarding the corporate, corporeal, and communal dimensions of eucharistic experience within its liturgical setting. It will be proposed, instead, that paying more attention to how Eucharist is experienced in its spatial, temporal, corporeal, and affective dimensions within the communal, ecclesial setting will provide a fuller and more adequate phenomenological account of it as genuinely human religious experience. Such an account might also tone down some of the emphasis on the excessive and extraordinary nature of this phenomenon, which often implies that if sacraments are not experienced in such intense fashion the person does not have genuine belief or is somehow at fault. A broader account of the liturgical setting for eucharistic experience will reveal not only how its "mystery" is manifested through and within the "ordinary" or even mundane experience, but also how such liturgical experience directs toward and prepares for eucharistic participation. That is to say, a phenomenological analysis of eucharistic experience requires an account of liturgical intentionality.

\section{Jean-Luc Marion: Eucharist as Abundant and Abandoned Gift}

The Eucharist is a frequent theme in Marion's writings. Already in his early God without Being — primarily a polemic tract against a certain kind of Heideggerianism in France-he argues for a theo-logy grounded in the event of the Eucharist (Marion 1991, pp. 139-58). ${ }^{2}$ The essay thus does not necessarily focus on Eucharist as religious experience but instead employs it to say something about the activity of theologizing. Marion proposes a "eucharistic hermeneutics" that would allow God to pronounce "correct" interpretation from the Word revealed in the "eucharistic moment" (Marion 1991, pp. 151, 153). ${ }^{3}$ He urges the theologian to move over to "God's point of view" and to speak theology only from this (essentially episcopal) perspective (Marion 1991, pp. 149-52). ${ }^{4}$ In a subsequent chapter in the same book, he provides an analysis of eucharistic presence that seeks to defend a particular account of transubstantiation in the face of interpretations that focus on the reception by the community in the attempt to combine a "subjective" and an "objective" perspective (Marion 1991, pp. 161-82). ${ }^{5}$ These two accounts have been extensively criticized, especially for their heavily hierarchical tenor (e.g.,

essay.) One should note also Robert Sokolowski's book on eucharistic manifestation (Sokolowski 1994), which draws on Husserl's phenomenology.

2 See also his essay "The Gift of a Presence" (Marion 2002a, pp. 124-52). This text analyzes the ascension narratives.

3 Or, in more detail: "The Word intervenes in person in the Eucharist (in person, because only then does he manifest and perform his filiation) to accomplish in this way the hermeneutic. The Eucharist alone completes the hermeneutic; the hermeneutic culminates in the Eucharist: the one assures the other its condition of possibility" (1991, p. 150). He explores this in more detail in his analysis of the story of the Emmaus disciples, which culminates in the recognition of Christ when he breaks the bread (and disappears). Here, also, Christ provides the correct interpretation and "intentionality" for what the overwhelmed intuition of the disciples cannot grasp. (Marion 2017, pp. 136-43).

4 Or, more succinctly: "If, first, theology as theology attempts the hermeneutic of the words in view, hence also, from the point of view of the Word, if the Eucharist offers the only correct hermeneutic site where the Word can be said in person in the blessing, if finally only the celebrant receives authority to go beyond the words as far as the Word, because he alone finds himself invested by the persona Christi, then one must conclude that only the bishop merits, in the full sense, the title of theologian" (1991, p. 153; emphasis his).

5 The language of unifying the subjective and the objective is employed on page 181. Interestingly, this second piece is "outside" the regular text (in an afterword called "Hors-Texte"), while the other essay on the Eucharist is the final chapter "inside" the text. Neither of the essays yet employs explicitly phenomenological language. In fact, in the second essay he says clearly that his "task here remains theological" (1991, p. 171). 
Mackinlay 2004; Wallenfang 2010). ${ }^{6}$ After developing his phenomenological approach much more fully in such works as Being Given: Toward a Phenomenology of Givenness or In Excess: Studies of Saturated Phenomena (Marion 2002c), Marion's later work returns to the topic of the Eucharist in several much more explicitly phenomenological essays (Marion 2017, especially chapters 8,10 , and 11). ${ }^{7}$

Probably the fullest account is his "The Phenomenality of the Sacrament," which can be said to represent his mature position (Marion 2017, pp. 102-15). ${ }^{8}$ He begins by contending that phenomenology is an appropriate method for Christian theology and the phenomena of Christian experience, because both phenomenology and Christianity start with the central notion of revelation or manifestation and seek to unfold its meaning. The Eucharist brings together visible and invisible-the invisible manifesting in some way through the visible elements-in a quintessentially phenomenological way. ${ }^{9}$ It is thus not inappropriate to speak of the Eucharist as a phenomenon. Marion explicates traditional models of the sacrament-as invisible substance in visible accidents, as invisible cause of a visible effect, or as visible sign of an invisible reality-and finds their phenomenological kernel to be that of a fully abandoned gift: In each case, the sacrament "gives itself without withdrawal to the point of abandon" (Marion 2017, pp. 106-8; the same phrase is reiterated after the analysis of each model). He concludes from this that "to define the phenomenality of the sacrament, one must see that within it the invisible is translated, delivers itself up, and abandons itself to the visible to the point of appearing in it as the invisible that it remains" (2017, p. 108). The gift of revelation can appear in the Eucharist precisely because it is given so fully that it protects its invisibility by being kenotically exhausted in the visible. We can never point to body and blood of Christ-they remain invisible-precisely because they are wholly manifested within the visible species of bread and wine. Incarnation is accomplished entirely and in full immanence; no remainder of pure transcendence is withheld, but all of it is given and delivered over.

This is of a piece with Marion's broader phenomenological project, which seeks to articulate a phenomenology in which the phenomenon takes the initiative and its manifestation and meaning are unfolded entirely from how it gives itself, rather than imposed on it by the consciousness of the one experiencing it. That is to say, some phenomena-such as rich cultural events, beautiful works of art, the intimate touch of loving flesh, the face of the human neighbor, or the manifestation of the divine-come to us in such overwhelming ways that we cannot impose categories or parameters upon them, but experience them as they give themselves in abundant, surprising, unpredictable ways, without being able to exercise control over them. ${ }^{10}$ Marion calls such experiences "saturated"

6 Marion defends himself against some of these critiques in his interview with Richard Kearney (Kearney 2004, pp. 15-32, especially pp. 21-22). See also my analysis of Marin's "spirituality of adoration" (Gschwandtner 2017, pp. 188-217) and the final chapter of my Degrees of Givenness (Gschwandtner 2014, pp. 170-92).

7 Many of the pieces included in this text (2017), as well as those in an earlier collection (Marion 2008), were originally articles in the Roman Catholic journal Communio. Marion was the first co-editor of the Francophone edition of Communio. The essays were thus originally conceived as theological pieces written for a Roman Catholic audience.

8 What follows in the rest of this paragraph is a brief summary of this essay. The essay was first published in 2001; it is confirmed by similar arguments in 2008 and his Gifford Lectures (albeit focused on the Trinity not on sacraments), published as Givenness and Revelation in 2016.

9 See also his analysis of mysterion and apokalysis in the Gifford lectures (Marion 2016, pp. 76-77). (An anonymous reviewer suggested that there might be a hidden Palamite influence in Marion's work, such that God's essence remains entirely transcendent and mysterious while manifestation occurs through the divine energies. It is certainly true that Marion stresses that we have no access to God as such and that the divine must always remain incomprehensible, while he also affirms that God is revealed and "effective" within phenomenality. Yet, although Marion often appeals to Dionysius the Areopagite and occasionally Gregory of Nyssa, he does not engage the later eastern patristic tradition and is occasionally quite dismissive of contemporary eastern Orthodoxy. He also rigorously rejects any language of ousia, essence, substance, or being for the divine and is critical of the Aristotelian language of energeia, especially as it relates to act and potency. Jones explores the patristic sources of Marion's thought in detail (Jones 2011).

10 He summarizes this also in the present essay: "By givenness, one must here understand the ultimate accomplishment of phenomenality, indubitable because it is perfectly reduced to immanence, such that it makes it possible to calibrate and accommodate all the degrees of presence, evidence, reality, and actuality, yet without itself being returned to them. The phenomenon thus recovers the sovereignty of its appearance only while being phenomenalized of and by itself, in showing itself from itself. Yet it attests this self only when the appearance enters into its appearing. And it enters into the appearing and commits to appear only if it gives itself. Nothing shows itself that does not first give itself. This rule of 
phenomena, because they "saturate" (that is, entirely fill and overwhelm) our intuition, rather than having to be constituted through the intentionality of consciousness. ${ }^{11}$ His overall project seeks to articulate a phenomenology of givenness in which such intense, rich, saturated phenomena could appear and their modes of manifestation be articulated via the impact they have on the recipient. The phenomenon gives itself fully to us, entirely on its own terms, thus effecting what he calls a "counter-experience," in which the recipient no longer imposes categories upon the phenomenon or directs his or her intentionality toward it in order to constitute it, but instead receives it as a surprising, unpredictable, unforeseeable, uncategorizable event. ${ }^{12}$ The Eucharist manifests even more fully and purely as such a phenomenon given completely and utterly as gift (don/donné), abandoned (abandonné) wholly to its recipients without remainder.

Indeed, Marion speaks of the Eucharist most often and most fundamentally as gift. ${ }^{13}$ Already in God without Being he stresses this dimension: "Eucharistic presence must be understood starting most certainly from the present, but the present must be understood first as a gift that is given. One must measure the dimensions of eucharistic presence against the fullness of this gift" (Marion 1991, p. 171). ${ }^{14}$ In other places, too, he discusses the Eucharist as a loving gift, given entirely and abundantly by God, to be received by us in similar kenotic abandon. ${ }^{15}$ In the breaking of the bread, Christ "gives himself to the point of abandoning himself like bread is distributed, abandoning himself like bread, like this bread, can concentrate all his presence in a gift, whether in a fleshly body or by taking body of the bread, always without any reserve whatsoever" (2002a, p. 133). The recognition of "unbearable glory" that occurs in the Eucharist, heightened by Christ's apparent absence or withdrawal, requires that we must now become models of Christ, playing a "trinitarian role" of "the place, the role, and the charge of Christ" (2002a, pp. 144-45). Christ is given so entirely in the gift that he is fully abandoned to it and does not remain isolable from it, to the point of withdrawing from straight-forward visibility (as in his disappearance at Emmaus). Like the saturated phenomenon, we are blinded by the appearance, must recognize it obliquely (e.g., in the breaking of the bread), and respond to it in kenotic abandon.

In "The Recognition of the Gift" he suggests that the Eucharist constitutes the supreme instance of gift or givenness, because in it Christ is wholly given to the point of death, in such a way that the gift can be continually regiven in the eucharistic elements (Marion 2017, p. 132). The Eucharist is the most perfect gift because "the real presence actually de-realizes the matter of the gift, which, paradoxically, in turn phenomenalizes the giver and allows the entire process of givenness to appear" (2017, p. 134; emphasis his). ${ }^{16}$ Eucharist thus displays the fullest kind of phenomenality, one that can serve as a paradigm for all phenomena (Marion 2017, pp. 133-35). Phenomena, as Marion has attempted to show throughout his work, give themselves to us; the more overwhelming and saturated they are,

phenomenality in general measures the legitimacy and possibility for any phenomenon to show itself according to the measure of givenness." (2017, pp. 110-11.)

11 As occurs in everyday or what Marion calls "poor" phenomena, where intuition only supplies some elements (e.g., the front of a book or side of an object, where we constitute the phenomenon by supplying the "back side" or reverse that is not intuited directly or the constitution of a circle where we have no intuition of a perfectly circular phenomenon at all, at least via perception). Marion contends that in these cases intention supplies the signification that is missing via concepts, while this is impossible in the case of saturated phenomena both because they are so overwhelming that they cannot be grasped via concepts and because it is fully given to intuition and thus nothing has to be supplied for its apprehension.

12 This is worked out most fully in Being Given, but also pursued in several subsequent texts.

13 For his broader analyses of the gift, see the "Sketch of a Phenomenological Concept of Gift" (Marion 2008, chapter 5, pp. 80-100), Book II of Being Given (Marion 2002b, pp. 71-118), and chapters III and IV of Negative Certainties (Marion 2015, pp. 83-154).

14 See also the section on "The Gift of Presence" (2017, pp. 176-78). The same title is employed for his essay on the ascension narratives in Prolegomena to Charity.

15 "The presence of Christ, and therefore also that of the Father, discloses itself by a gift: it can therefore be recognized only by a blessing. A presence, which gives itself by grace and identifies itself with this gift, can therefore be seen only in being received, and be received only in being blessed" (2002a, p. 129). This becomes the supreme task of the disciples, the church, and ultimately all of humanity (2002a, p. 130).

16 He also reiterates here the idea that we must see the gift from the point of view of the giver, God, thus applying "the proper hermeneutical decision," that is, "the hermeneutics of givenness" (2017, p. 135). 
the less they are open to prediction or manipulation (or constitution) from the experiencer and the more abundantly they come and displace, unsettle, overwhelm, bedazzle the one exposed to their arrival. Eucharist is the most intense, most saturated, most overwhelming, most bedazzling of such phenomena to the point that it may appear no longer as a saturated (saturé) phenomenon, but as an erased (raturé) phenomenon. ${ }^{17}$ It gives itself so fully that nothing remains of it.

Eucharist, for Marion, thus phenomenalizes as gift, as supremely saturated phenomenon, that is to say, as a phenomenon that overwhelms us with its givenness, startles and bedazzles us, presents as infinitely more than we can grasp, and yet at the same time gives itself so wholly that it withholds nothing, that the entire divine abundance is offered within it. The sacrament therefore reorients us, makes us devoted or given over to it (adonné), as we receive its abandon as far as we are able without exercising control over it, imposing concepts upon it, or determining it in some fashion-all of which would be impossible due to its overwhelming character. Its dazzling and abundant character is not always visible, however, both because this invisible abundance is hidden within or behind the visible and because we are not always able to bear it. We can only receive-and thus allow to manifest as a phenomenon-what we can bear or are able to see. In that respect, although the phenomenon of revelation offers itself entirely and we are unable to impose parameters upon it or control its manifestation, it still requires a recipient to serve as the screen of manifestation, someone to respond to Eucharist in awe and adoration, hence to "phenomenalize" it. Marion offers us a phenomenology of the Eucharist that is focused almost exclusively on how the phenomenon is given to us, namely as saturated, overwhelming, bedazzling, abundant gift, to which we are called to become wholly devoted.

\section{Jean-Yves Lacoste: Eucharist as Eschatological Anticipation}

Lacoste has also returned to the topic of the Eucharist several times. Drawing heavily on Heidegger for his phenomenological parameters and presuppositions, Lacoste focuses on several dimensions of the eucharistic experience, such as the phenomenological status of the elements, the affectivity (Befindlichkeit) involved in the experience, how intuition is at work in sacramental apprehension, and the "logic" of the sacrament as one transcending death and challenging the "logic" of the world. Lacoste's overall project posits itself as a phenomenology of "liturgy," but this does not refer to ritual or worship (i.e., what is meant by liturgy in theology); instead it designates a broader phenomenological "being" before the Absolute. ${ }^{18}$ This is essentially an analysis of ascetic experience as wholly kenotic, defined by radical abnegation, liminality, and dispossession. Throughout Lacoste relies heavily on Heidegger, taking his analysis of Dasein or being-in-the-world as the "secular" or neutral starting point for the human condition and envisioning a confrontation with the divine from that basis, while also suggesting that such an encounter with the Absolute may lead to the displacement or reorientation of human being-in-the-world and our being-toward-death. Eucharist is a boundary experience that resituates us vis-à-vis the world and everyday life.

In one of his early essays, Lacoste actually explores liturgy not simply as existence coram Deo, but refers more explicitly to ecclesial liturgical elements (Lacoste 2005, pp. 93-103). He argues that there are neither subjects nor objects in liturgy; the things of liturgy "appear by refusing their objectification"; they "appear in a play that excludes all grasping, whether this be in the mode of representation or taking possession" (2005, p. 97). They are not objects or tools, because they break with our regular experience of the world. ${ }^{19}$ There is no "representational consciousness" in liturgy. He thus agrees with Marion that

17 He also claims this of orgasm and for the erotic phenomenon more broadly (Marion 2007, pp. 138, 144, 153).

18 "The reader who has seen the term [liturgy] arise in the table of contents of this work must therefore be advised: what 'liturgy' designates in these pages is, in fact, as convention would have it, the logic that presides over the encounter between man and God writ large. I am not denying that this encounter is also attested to in worship, or that worship has an order and that this order is rule governed. But the limits of what I understand here by 'liturgy' exceeds the limits of worship." (Lacoste 2004, p. 2).

19 "Things in general, and those of the liturgy in particular, are such by virtue of a rupture or a separation" (2005, p. 97). Instead, like art, "they are signs and symbols" (2005, p. 97). 
traditional phenomenological modes of experiencing phenomena do not apply to our being before God: The phenomena of liturgy cannot be constituted via our intentionality or as representations within consciousness. We must disqualify objectifying manipulation and representational consciousness, and instead approach liturgical phenomena with "vigilance and a respect" (2005, p. 98). Drawing again on Heidegger, Lacoste also argues for a coaffective experience of the "we" (Mitbefindlichkeit) in liturgy. ${ }^{20}$ Heidegger stressed that we always find ourselves in the world already among and with others. Liturgy, in Lacoste's view, disqualifies these "'everyday' modes of the 'with'," but can instead propose a different kind of shared experience of affect, at least by anticipation, in terms of a "desire for communion" (2005, pp. 99-100). Although Lacoste does no analysis specific to Eucharist in this essay, it is already clear that he does not regard the eucharistic elements as objects or even tools. We experience them otherwise and must come to them with a different sort of affectivity, namely approaching them with awe and veneration, maybe even with joy.

He addresses sacramental experience more explicitly in other contexts, all of which stress that eucharistic experience cuts across our field of experience and points to an existence that would be neither mortal nor existential, thus undoing our condition as being-in-the-world and being-toward-death in the Heideggerian sense (Lacoste 2011, p. 301). Lacoste reiterates repeatedly that sacramental experience, although "parousial" in character, is limited to this world; no sacraments are needed in the afterlife because we will be immediately in God's presence. Although the sacrament must be talked about in terms of presence, this presence ruptures the closure of the world and undoes the logic of the object (Lacoste 2011, p. 302). ${ }^{21}$ This sacramental presence is not sensed, however; it is not a matter of theophany, but rather a "cryptic" revelation. Presence is sensed within the limits of the present, such as the species of bread and wine, yet cannot really be apprehended there securely. Joy over this abundant gift would always be partial and in anticipation only. ${ }^{22}$ Our affective responses to the infinite remain limited and the phenomenon must unsettle (rather than comfort) us in some way. ${ }^{23}$

For Lacoste, this is always a matter disrupting the order of the world and of undoing its logic, pointing to a beyond the world, and beyond time. ${ }^{24}$ Thus, "the sacrament sanctions our finitude, for there are sacraments only for mortal beings. All the same, in the world of life, for the one who recognizes it, the sacrament opens a space in in which this finitude, whether it is unsettled or tastes the joys of quietude, is initiated into a duration which is not defined as being-toward-death. This bracketing of being-toward-death in the experience of the sacrament is as fragile as can be" (2011, pp. 306-7). Because phenomenology only deals with the appearing of the visible within the world and history, it can never reveal the invisible or what is beyond the world and history. The sacrament opens a way to "transcend our being-in-the-world and our historiality," but only in the most tentative of senses. ${ }^{25}$ For Lacoste, life is always "caught between quietude and disquietude," thus "the limits of 'spiritual' experience always escape us" (2011, p. 311). Ultimately, sacramental experience is a non-experience, because it cannot be sensed or articulated within earthly parameters of emotion, affect, objectivity, place, time, or other conditions of experience. ${ }^{26}$

20 "And about men who want to associate liturgically with angelic praises, it must be conceded that they are a little bit more than just together" (2005, p. 99).

21 E.g., "where there is sacrament there is henceforth no longer any object" (2011, p. 302).

22 "No more than absolute knowing there is no absolute affectivity" (2011, p. 303).

23 "The infirmity of affections toward the infinite that it can only grasp partially certainly does not give rise to (or cannot give rise to) a disaster of the believing consciousness. All the same, it does give rise to a kind of disquietude (and we should be worried if that were not the case): we encounter here a phenomenon in its most exemplary reality" (2011, p. 304).

24 "Nevertheless, within the world of life, it points to the irruption of a beyond the world and, if we limit life to its world, a beyond life" (2011, p. 304).

25 "We can all the same do better and respect what gives itself in the sacrament to the double experience of affectivity and thought. And doing better would thus mean to admit that the sacrament and everything that participates in its logic makes it possible for us to transcend our being-in-the world and our historiality" (2011, p. 308).

26 The idea of nonexperience (including the non-place and non-time of liturgy) is worked out most fully in chapter 3 of Experience and the Absolute (Lacoste 2004). 
Lacoste's fullest account of the Eucharist is in an essay on "sacramental intuition" (Lacoste 2015, pp. 59-95). This essay explores what he explicitly calls "the phenomenality of the sacrament" (2015, p. 71). Like Marion he employs the traditional idea of the visible referring to an invisible reality, that is to say, appearance or manifestation is here actually a matter of disappearance or of what does not appear visibly. Although bread and wine clearly are phenomena that can be seen, touched, and tasted, as Eucharist they must always appear as more or other than themselves. They are not simply objects; a phenomenology of the sacrament has to go beyond both ontological (or epistemological) language, as well as the logic of sacrifice or offering. While bread and wine appear "within the world," the sacrament points beyond the world and its logic $(2015$, p. 76). The sacramental and the corporeal order are linked, yet the sacrament "belongs to an economy of the provisional" (2015, p. 79). We do not have a straightforward affectivity or sensation or "sentiment" in the phenomenological experience of sacramentality, but rather a "presentiment" or anticipation. There is nothing necessarily "felt" directly in our experience of the sacrament, but something is anticipated via faith $(2015, \mathrm{pp}$. 80-81). The sacrament instantiates a constant play between presence and absence, appearance and disappearance, history and eschaton, world and parousia.

Here Lacoste differs from Marion: Although he agrees that sacramental experience is difficult to phenomenalize, this is not the case because it is so overwhelming, but because it goes beyond any experience of being in the world. It is not that too much intuition is given that our intentionality could not grasp or constitute, but rather that there is no intuition involved at all, that intentionality is utterly incapable of apprehending the Absolute $(2015$, p. 86). It is not that God is given so fully that we become too overwhelmed to bear this revelation, but that the Absolute is so kenotically absent that no experience can appear in our present world at all. We would have to step across the liminal line to the eschaton and that can only be anticipated in the most elusive fashion. It would require a radical reorientation and disintegration of all our present parameters of perception or apprehension. Lacoste therefore insists on a context of faith for an experience of the Eucharist; "sacramental experience presupposes a world where man exists already before God," which is not the present world. Thus, he finds it a truism that "sacramental intuition cannot be our first experience of God" $(2015$, p. 87). We must believe in the "world of faith" in order for sacramental experience to "happen"; faith must prepare us; there is no "primordial sacramental position" $(2015$, p. 89$) .{ }^{27}$ He insists over and over again that sacramental intuition always cuts across the world and puts it into question: Sacramental intuition is that "of a limit and of our impossibility of getting across it here and now" (2015, p. 92). Thus, for Lacoste, this is a phenomenality of believing rather than of experiencing (2015, p. 93).

For Lacoste, the experience of Eucharist or sacrament is of a piece with his broader phenomenological analysis of being-before-God or the Absolute. It cannot be experienced or described within the traditional (in this case primarily Heideggerian) parameters, because the Absolute never appears or is experienced within "normal" time and place, objects or sensory perception. Rather, such encounter always presents a challenge to our regular way of being and unsettles it radically. It undoes death in the anticipation of eschatological life, undoes time via the parousia, undoes place and the logic of the world by pointing to an elsewhere. Ascetic, kenotic, or eucharistic "non-experience" provides a tantalizing hint of this anticipation, yet it can never really be experienced or encountered in this present life within this world, but remains wholly mysterious.

Although for Lacoste the experience of "liturgy" or sacrament is thus always a non-experience or an experience of abnegation or dispossession, rather than one of fullness, excess, or saturation as in Marion, ultimately their accounts of response to the phenomenon are quite close: For both, the eucharistic (or ascetic) recipient must give him- or herself over to the Absolute in total kenotic abandon and neither allows for intentionality or processes of constitution in regard to the eucharistic

27 Although I cannot explore this further in the present context, I would say instead that liturgy can prepare for and cultivate faith and thus may well function in primordial ways. 
phenomenon. Lacoste does actually sometimes use language of gift, excess, and an ambivalent presence in ways that parallel Marion's descriptions. Yet, he exacerbates the tension between visible and invisible even more strongly than Marion; almost everything is deferred to eschaton and parousia, even though there will be no Eucharist or sacraments there. Lacoste's analysis thus can be said to focus almost exclusively on eucharistic reception: The ways in which it is a wholly liminal experience that challenges our ordinary ways of being and calls us to an utterly kenotic existence of total abnegation, albeit one that cannot be lived here and now, is always only hinted at in the most elusive fashion. Ultimately, there cannot really be a phenomenality of the Eucharist for Lacoste, but only an undoing of phenomenality by Eucharist, an anticipatory displacement or dissolution of our experience and its phenomenological parameters.

\section{Emmanuel Falque: Eucharist as Erotic Participation and Incorporation}

In many ways, Falque can be said to be responding to these rather extreme and liminal accounts of religious experience, attempting to temper their excess and recover a stronger sense of the immanence of Christian experience as fundamentally incarnational, especially in regard to the sacrament of the Eucharist. ${ }^{28} \mathrm{He}$ also considers the (Roman Catholic) liturgical context more fully, even explicitly quoting from the liturgical texts for the eucharistic liturgy of the mass. In general, philosophy (as phenomenology) and theology are much more fully linked in Falque's writings; he even suggests that "the more we theologize, the better we philosophize" (and the reverse) (Falque 2016, p. 148). ${ }^{29}$ Two texts are especially important here. His essay "This is my Body" is explicitly focused on developing a "philosophy of the Eucharist," that links an analysis of eucharistic "incorporation" with those of the erotic and the suffering body "spread out" (as on a bed) (Falque 2015a, pp. 279-94). In his book on the Wedding Feast of the Lamb he develops a phenomenology of the body that culminates in a theology of Christian marriage and a theologico-phenomenological analysis of the Eucharist (Falque 2015b).

His eucharistic discussion considers four aspects of the experience, what he calls its heritage (the lamb), its content (the body), its modality (eros), and its aim (abiding). ${ }^{30}$ He suggests that this experience can only be expressed by questioning and pushing beyond the limits of philosophy, holding philosophy and theology together or even transgressing the boundaries between them. He criticizes the preceding French phenomenological tradition for having separated "body" and "flesh" in such a way as to reinstitute the distinction between body and soul they originally sought to overcome by simply attributing to the flesh what was traditionally predicated of the soul. To get beyond this dichotomy, he develops the notion of the corps épandu, that is, the body as "spread" or "splayed" out. He employs this as a notion of the body that takes account of both its organic and its experienced dimensions, neither an "extended" body (corps étendu) in Descartes' sense nor the "lived body" (corps vécu, Leib, often translated into French as chair/flesh) in Husserl's sense. We should not privilege the lived experience of the body over the organicity of the body, as recent philosophy has done.

Falque suggests that the body stretched out on the cross is phenomenologically parallel to the body splayed out on the sickbed or the body spread out on the nuptial bed. ${ }^{31}$ They are connected through what he calls our "animality," our fully embodied experience of the chemical and organic substructures of the body, the psychological "chaos" of passions, impulses, and emotions, and our biological physicality, especially in its breakdown of illness, aging, and death. The Eucharist affirms

28 His most explicit response to a variety of phenomenological thinkers is found in his Loving Struggle (Falque 2018).

29 In a sense this is the central thesis of the entire book.

30 "It is therefore advisable to question the entirety of human experience, everything involved in the Eucharist, in order to be transformed by God: animality (Eucharistic heritage [the figure of the lamb]), the body (Eucharistic content [this is my body]), eros (Eucharistic modality [a body given]), and finally abiding (Eucharistic aim [remain in me and I in you])" (Falque 2015a, p. 280).

31 One should note that eros as it occurs within marriage and only via a traditional heterosexual union is central to his analysis of such nuptials. This entails for him a particular account of sexual difference as complementarity that allows women to be more fully "feminine" and men more fully "masculine." 
not that God becomes an animal (cf. the prohibition of portraying Christ as an animal at the Council of Trullo), but does claim that God enters our animality, as the mode of access to human corporeality (2015a, pp. 282-83). Christ assumes the full "chaos" of our passions and impulses (2015a, p. 283). Falque distinguishes this animality (as organicity) from bestiality (a descent into sin) and from a transformation into a full humanity or even divinity via the resurrection. We must return to a full affirmation of Christ's body and its real materiality; he assures us that this leads neither to cannibalism nor to a purely symbolic interpretation (2015a, pp. 286-87). Thus, this affirmation of Christ's corporeality in the Eucharist can be likened to the experience of the body in illness or within erotic experience. In these cases, there is a sharing of forces, in which two bodies become a single flesh via spousal union or sexual difference, which prefigure the Eucharist (2015a, pp. 290-93).

Falque pushes this further in the third book of his trilogy on the Paschal Triduum, The Wedding Feast of the Lamb, in which he equates the "modality of eros" with the "modality of eucharisticized body"; indeed, eros emerges as a form of eucharistic sacrifice (Falque 2015b, pp. 47-49). He again reiterates that Eucharist transforms our embodiedness from mere animality to full humanity (2015b, p. 199). Holding on to the notion of transubstantiation as giving an account of real presence, he suggests that there must be a real conversion of the bread/body: "This is my body points above all to a body made of flesh and blood that is the body of the Word incarnate, one that is in another mode (not localized but transubstantiated) and has another presence (of the Resurrected Christ and not simply of the historic Jesus). To take communion is to participate in the life of the Resurrected One, not to share fragments of a flesh that it would be forbidden to chew" (2015b, p. 201). It is significant for him that Christ's body is given as bread, thus as nourishment. ${ }^{32}$ Thus, Falque suggests a reversal is at work here: "the becoming-flesh of the body (Resurrection)" corresponds to "the becoming body of the flesh (Eucharist)" (2015b, p. 203). We eat Christ and are eaten by God in what he calls a phenomenology of "anti-digestion" and "ingurgitation," inasmuch as it functions to assimilate and incorporate us into the divine life without losing its physical and visceral connotations of chewing and digesting. ${ }^{33}$

He explicitly labels this account phenomenological and contends that phenomenology can help clarify what we might mean by incorporation. ${ }^{34}$ This again brings together philosophical and theological dimensions: "In presenting myself for communion, and this time in the mode of incorporation and not simply of assimilation, I do not simply bring forward my own concerns and the sufferings of my flesh; he brings forward his divine mode of being in his body, through which he embraces and takes responsibility for all the sufferings of our flesh" (2015b, p. 208). We must be "integrated and transformed in God" via a double movement, "that by which the Word is incorporated or assimilated into the bread in its kenosis (subjective genitive), and that by which we are ourselves caught in this act of integration and transformation (objective genitive).... the eucharistic sacrifice ensures that we are ourselves offered, rather than that we consume it" (2015b, p. 209). He concludes by stressing again that Eucharist is able to transform our animality into a fuller humanity: "transubstantiation, incorporation, and consecration constitute three stages of a this is my body that is capable of taking on and transforming our humanity, and indeed also our animality, in the expectation of an adoration that can bring us back to our nature as created humans and that integrates us in a definitive and radical filiation" (2015b, p. 209). We have thus moved significantly from the initial affirmation of organicity and animality as full (albeit secular) humanity to an important distinction in which only Christian and explicitly eucharistic experience (including of suffering and resurrection) constitutes true humanity; the "atheist" experience remains a lesser "animality" only. This sort of slippage occurs frequently in Falque's work,

32 "In making his body a this, the Christ given for us, in his humility or as his humus (earth), borrows the path of the thing, just as the bread given to us serves as nourishment to fortify us" (2015b, p. 202; trans. lightly modified).

33 "Nobody simply eats God, but we are always in some respect eaten by him" (2015b, p. 205). "That which is assimilated by us, in the unique case of the body of Christ, is what assimilates us; or rather, paradoxically, it incorporates us even into Christ-there whom we eat" (2015b, p. 206).

34 "We can say that what goes for phenomenological intentionality applies also to eucharistic incorporation" (2015b, p. 207). 
which always wants to start with the "human as such" (l'homme tout court) as shared philosophical basis and yet frequently thinks of the Christian experience as more fully phenomenological and more fully human.

In either case, he maintains that the Eucharist reactualizes the mystery as phenomenon each time we participate in it: "Because we participate in the Mass consciously, or rather, through our consciousness, we are inclined to forget the silent experience of the body-to-body [referring to hand-to-hand combat, as in Jacob's struggle with the angel] of human and God that should guide us here" (2015b, p. 210). Our whole body must participate in this. ${ }^{35}$ Falque stresses that this involves not only eating the body, but also seeing and loving God through it in order to achieve "incorruptibility." ${ }^{36}$ Here we have moved back to a theological analysis, as presumably phenomenology has no access to an experience of incorruptibility. At the same time, Falque continues to stress the sensory dimensions of the experience: "In the eucharistic Adoration, none of our senses, up to and including that of sight, will be forgotten as we try to come to an understanding of the One who, by the act of manducation, will be tasted" (2015b, p. 213). They are, however, always quickly assimilated to theological affirmations: "After all, when I see him, in his body and under the stable form of the species of bread, I think-no, I believe-that he sees me: me, in my body that lives and shares with him that mute experience of a body-to-body, where my sense and my interior Chaos will emerge so that I take responsibility for them and they are changed" (2015b, p. 215). Here also he ends by superimposing his account of the Eucharist on an account of marriage or sexual difference and references to illness (2015b, p. 223). ${ }^{37}$

Thus, although Falque's discussion is far more attentive to the concrete ecclesial instantiation of Eucharist (citing from the texts of the Roman mass) and its theological heritage (with frequent references to theological controversies, patristic and medieval texts, and various historical eucharistic positions) and also stresses its sensory and affective phenomenality far more fully than either Marion or Lacoste do (via the analysis of organicity and animality), the constant conflation of these two dimensions is problematic, because it makes the argument by assimilation or even wholesale merging of phenomenological and theological assertions rather than by showing how these dimensions are actually parallel or linked. We slip from phenomenological corporeality or animality to theological transformation into incorruptibility rather too smoothly, in a way that certainly cannot be sustained on purely phenomenological terms. The phenomenological parameters are here employed in order to justify essentially theological positions without further phenomenological description of Eucharist as encountered or lived in human experience. Theological affirmations about the meaning of Eucharist are simply assumed and superimposed on the phenomenological interpretation of corporeality. Sometimes the reverse occurs, phenomenological assumptions about human corporeality are imposed on the theological event and simply taken to be present and applicable there without showing in any substantive fashion how that might be the case. Although the "Rubicon" between philosophy and theology is surely crossed here, such crossing may have been too hasty.

The superimposition of erotic and palliative experiences on Eucharist seems especially problematic. Does the body "spread out on the hospital bed" really function like the body in erotic experience and can both be likened to what body means phenomenologically or how body is experienced when one participates in the Eucharist? That seems highly questionable. The hospitalized body is not experienced as an eroticized body; indeed, it would be quite problematic if that were the case. Although they

35 "The eucharistic memory cannot then remain indifferent to the body, to its weight and its wounds that are endlessly reactualized; otherwise, it risks being held and kept simply by the consciousness, as the memory of a past that has been superseded. Everything is inscribed in our bodies, and nothing has been forgotten of the body of the Resurrected One in the total of the eucharisticized bodies. By eating his body and drinking his blood, we don't simply celebrate the memory of an event, even if that event was foundational for all humanity. We drink the blood of his life that flows as far as our veins, and we eat the flesh of his body that feeds us even in our inmost organs" (2015b, p. 212).

36 "It is not enough to eat him to participate in this mode of incorruptibility. We can still, and we should still, lead ourselves to see him and to love him as the power of transformation" (2015b, p. 213).

37 These superimpositions or conflations also return in an essay on palliative care: (Falque 2019, pp. 91-116). 
may share a kind of vulnerability that cannot be expressed either in terms of extension or purely affective flesh, it has not been shown that this vulnerability is experienced in the same way, or is phenomenologically of the same sort. Neither is Christ's "body" (or the bread) experienced as either hospitalized (like the sick or dying body) or eroticized (like the body of the beloved). Do we "intend" these bodies in the same way, are directed toward them as phenomena in parallel fashion? Or are their intuitive experiences significantly alike? Surely our experience of chewing the bread-even in all its visceral physicality—is quite unlike our experience of touching or dressing someone's wounds or our experience of caressing or copulating with beloved flesh. These phenomena are neither of the same kind (Wesen), nor are they experienced in a similar fashion as regards their phenomenality, whether in terms of intuition or intentionality. There is little meaningful similarity here that could be phenomenologically discerned within the horizons of the experience. Thus, although Falque's eucharistic phenomenology certainly stresses its corporeal dimensions far more than Marion or Lacoste do, this corporeality comes with problematic assumptions that conflate different types of corporeal experience in a way that does not necessarily illuminate how corporeality is at stake in eucharistic experience specifically. How else, then, might a phenomenological analysis proceed?

\section{The Phenomenality of Eucharistic Experience in Its Liturgical Context}

How might it be possible to describe the experience of Eucharist in purely philosophical terms, that is, in terms of how it appears to human consciousness? Can a religious phenomenality, such as that of sacramental experience, be discerned and depicted philosophically? An analysis might proceed in three steps: First of all, Eucharist is a fully corporeal, sensory, and affective phenomenon that occurs within specific temporal and spatial dimensions of human experience, usually in the context of a "religious" (normally ecclesial) setting. Secondly, in a way ignored by almost all the philosophical accounts (and sometimes even by theological ones), Eucharist almost always happens within the specific rites of various Christian liturgical traditions, thus within a broader context of liturgical experience, what we might call phenomenologically its horizon of experience. Third, this liturgical context or horizon gives rise to or at least seeks to shape a particular kind of intentionality that is directed toward the phenomenon of the Eucharist in specific ways. How might such an analysis and depiction be useful? A phenomenological analysis of the human dimensions of participating in this religious ritual may enable us on the one hand to understand more fully why humans engage in such rituals, that is, enrich our philosophical understanding of the meaning of human experience. On the other hand, it may also provide methodological tools for a theological interpretation of Eucharist (although that implication is not pursued in the present essay, but left to the theologian to explore further). Let us take each of the three (interrelated) dimensions in turn and then draw out some preliminary philosophical implications.

\subsection{Eucharist as Phenomenon}

How does the phenomenon of eucharistic participation present itself to our consciousness? How do we sense, perceive, experience, or apprehend it? How do we experience the elements? How do we see, touch, or taste them, in what manner do they impact our perceiving or apprehending? What are the concrete parameters within which this sacramental experience appears as Eucharist? In its most mundane sense, Eucharist is experienced first of all as a concrete phenomenon within the world that has tactile, sensorial dimensions: The plate and chalice are seen; the institutional texts or anaphora are heard; the bread and wine are tasted, even smelled; depending on the tradition, various elements (the host, the chalice, a spoon) are touched with either hands or lips. These sensory elements can be observed and described; they can be likened to other experiences of sensing, touching, tasting and distinguished from them via imaginative variation, by examining how they appear to consciousness similarly or differently. In each case, this would not be a description primarily of a purely subjective experience of the sacrament at a specific moment, but an analysis of how it generally or usually appears, how it is experienced within the parameters that make it the sort of experience that manifests in recognizable ways. 
The sensory experience also arouses emotions and affects. The participants "feel" the eucharistic bread and wine not only in a purely tactile sense, but also in terms of its affectivity. Often the experience is approached with awe and veneration, sometimes it generates joy or peace, almost always is it experienced with other people and thus as a communal event in which affect is shaped significantly by what transpires within the participating group and not just the individual. Eucharist is also always experienced at a specific time and place, even when it is taken to a hospital or sickroom rather than consumed in church. Especially the ecclesial time and place function to situate the experience of the Eucharist; contra Lacoste, it is never a disembodied, atemporal, aspatial experience, but always one that involves setting aside time, coming into a place, as well as corporeal movement and gesture. This corporeal dimension is immensely important: Participants bow or kneel, fold their hands or open them for reception, come forward, cross themselves or fold their hands over their chest, kneel at an altar rail, and ultimately return to their seats or place to stand, finally leaving the church altogether, yet maybe with the taste of wine and bread still on their lips. Eucharist thus involves our bodies, how we move and position ourselves, the gestures with which we celebrate and receive, and obviously the activities of physically receiving, chewing, drinking, swallowing. Furthermore, the eucharistic elements are not simply contemplated (except in the Roman Catholic practice of eucharistic adoration), they are eaten and consumed, ingested into our bodies, thus become part of us in some form.

These "elements" thus clearly do not appear simply as objects that can be moved around or manipulated at will (in this respect Lacoste is entirely correct). Nor do they manifest primarily as tools that are useable or useful in a kind of utilitarian fashion. But they do not simply come "over" us or fall upon us. Rather, our experience of them is evidenced by the way we treat them: We process with them, hold them up for veneration, approach them with awe or reverence, touch them with a mixture of reluctance and eagerness. We also do not leave them as they are, but speak signifying words over them, break and pour them, ultimately consume them. We share them; Eucharist is essentially plural and communal experience. The physicality of the elements is clearly significant (highlighted by some of the liturgical texts used for the rite in several traditions); otherwise we would not treat them in this fashion. Falque is right to stress the corporeal dimension; Eucharist is not a purely "spiritual" experience but involves physical bread and wine, eating and drinking. Eucharist manifests to consciousness in physical, visceral, material ways, but at the same time conveys a significance within the experience that suggests that this is not mere physicality, but that the physical conveys a meaning that is broader than its "objectivity" or materiality. These two dimensions cannot be separated in eucharistic experience: It is not that there is the "visible" and physical on the one hand (bread and wine) and the "invisible" or spiritual on the other (body and blood of Christ), but it is precisely the physical or material that signifies as more than itself. Materiality signifies as "sacred" (i.e., set apart) in some fashion and this is conveyed within and through the concrete (albeit not purely subjective) experience.

Such an analysis of the phenomenon can be deepened by examining how it appears to memory, anticipation, or imagination, not merely to concrete sensory perception. That is to say, Eucharist signifies not only via the moment in which it is consumed and the tactile dimension of that experience, but also through the ways in which that experience is prepared through the memory of previous eucharistic participation and the anticipation of future partaking. More narrowly, the moment of touching and tasting is informed through the retention in memory of the anaphora or institution narrative that has just been proclaimed, the resonance of the Lord's Prayer that has often just been prayed, the lingering memory of the exchange of peace, the touching of hands or embrace. The anticipation of participation, as one stands in line waiting for others to drink from the same cup, is similarly a significant part of the experience of Eucharist in many Christian traditions. The "moment" of eucharistic participation is thus distended through memory and anticipation. All these and surely many other dimensions can be depicted and unfolded in much more detail and described as part of the phenomenon of eucharistic experience. 


\subsection{The Liturgical Horizon}

Yet, maybe even more significantly, Eucharist is always experienced within and against a larger liturgical horizon. The moment of eucharistic participation rarely happens in isolation; it occurs at the height of an entire ceremony, that is itself part of a larger liturgical experience encompassing the entire liturgical year with all its feasts and fasts and varied celebrations. Eucharist may well be experienced differently on a weekday than a Sunday, during advent rather than at the Paschal vigil. Some of its signification shifts through the meaning given by the specific liturgical context. ${ }^{38}$ More fundamentally, Eucharist, as experienced within liturgy, requires entering a "sacred" building, i.e., a building set aside for this use and often decorated and prepared in lavish fashion; it involves positioning oneself in certain ways, cultivating a particular attitude that can be analyzed in terms of openness, of contrition, of celebration, and so forth. All the phenomenological dimensions just mentioned for the moment of eucharistic experience specifically are important elements of the larger liturgical context as well.

Spatiality and temporality are even far more significant here or at least emerge more fully. For example, the tension between anamnesis and eschatological expectation as they are expressed in various eucharistic anaphoras reflect a particular temporality within liturgical experience more broadly, as does the cycling between feasts and fasts throughout the liturgical calendar. The back-and-forth between celebration and contrition, the modes of liturgical repetition, the ways in which remembered past and anticipated future are brought into the present experience all shape the horizon against which Eucharist (and, indeed, other sacraments) is phenomenalized. They are not isolated instants frozen in time, but extended and repeated moments within a larger liturgical temporality that gives meaning to the particular experience. Similarly, the "sacred space" in which Eucharist is experienced provides a liturgical setting. We do not simply eat bread in a perfunctory or haphazard fashion, but we consume it after entering a space that has been set aside for liturgical gathering, a space that has been deliberately planned, organized, decorated over centuries of tradition, thus endowing it with an experience of spatiality that differs from other experiences of eating.

The same goes for corporeal, sensory, and affective dimensions. The liturgical context illuminates how we handle and treat and approach the elements, prepares us for their reception. The participants' bodies do not suddenly materialize out of nowhere when they go up to receive the bread and wine, but they have been standing, sitting, or kneeling throughout an entire rite that has prepared them for reception of the sacrament and provides a context for it. Particular movements, postures, and gestures have been exercised throughout the liturgy in meaningful fashion. Such postures and gestures orient us toward the sanctuary, express our veneration or our penitence, prepare our bodies by inscribing the liturgical movements upon them, often to the point where they become almost automatic and enter us deeply. We experience our bodies as oriented toward the eucharistic event and as prepared through listening to music, prayers, homily, as well as bells and other sounds, via seeing burning candles, beautiful chalices, colorful vestments, and other implements, via smelling incense, ultimately to touch and taste the eucharistic elements. The experience of affect is similarly not limited to the moment of the Eucharist itself, but the broader liturgical context prepares our affectivity in manifold and recognizable fashion; some emotions are explicitly generated by the rite (or at least the rite seems geared at generating such affect), some are involved in more subjective ways. We raise our hands with awe, we bow in veneration, we sing with exultation, we meditate with reflection; all these and many more are at work in liturgical and eucharistic experience. Isolating the eucharistic moment from the larger liturgical context fails to take seriously the ways in which consciousness is prepared to

38 At the same time, it is worth noting that in most Christian traditions, the eucharistic liturgy itself undergoes the fewest changes and thus has the most stable signification. For example, vespers and matins (or vigil) in the Orthodox tradition have far more "moveable" elements that differ depending on the occasion than the eucharistic "divine liturgy." And although even the more scripted Western rites (e.g., Roman Catholic or Anglican) have now adopted a variety of eucharistic anaphoras and cycle between them, these are still fairly stable. Yet, the experience of Eucharist is clearly not wholly identical on every occasion but influenced by the temporality of the church year and even its spatiality (e.g., in a ceremony held outside). 
experience or apprehend, how it is directed toward revelation or manifestation, how it becomes the very context for such manifestation.

It is also worth noting here that such sensory or affective dimensions are rarely of the utterly overwhelming character described by Marion; liturgy does not completely bedazzle us, totally sweep us away, but often has a far more mundane character. Regular participants in liturgy become habituated to it; its modes of repetition function to inscribe it on their bodies, generating consistent emotions or moods of expectation. In this way, the larger liturgical context forms a liturgical disposition that is marked in sensorial, affective, and corporeal ways. Our bodies and emotions become prepared for liturgy and Eucharist through the cycles of repetition and the habituation they engender. Indeed, the experience may be more "saturated," certainly richer and more meaningful, when it is carefully prepared and anticipated, when participants know what they are doing and how to orient themselves toward the experience. Nor is boredom-as Lacoste often insists must be involved because we are not yet in the eschaton-necessarily present only or primarily because we are too tied to the world and have not undone, annihilated, or suspended it. It may certainly be true that the logic of aspects of religious experience, including the Eucharist, challenges aspects of the "logic" of the "world" but it cannot annihilate it entirely or wholly, because otherwise no experience would be possible at all. ${ }^{39}$

Both in terms of the (extended, not punctual) moment of Eucharist itself and the broader liturgical context, the experience is almost always a communal one: One participates with others, in most Christian traditions all drink from the same cup and share the same bread; the community has gathered and sung and listened and venerated together. If theologically we affirm that both Eucharist and church in some way constitute "body of Christ" this is suggested on some level even by the experience itself inasmuch as it occurs within community, is received and passed on to others, gathers the congregation together and in visual, auditory, even tactile ways, links us to each other, shapes an experience that at least for a short time knits us together as one. Eucharist is rarely (and liturgy even more rarely) experienced as a purely individual event, but its very experience is shaped by the communal context within which it occurs. Like feasting, its experience requires the communal dimension of plural participation in order to function as experience of Eucharist. Its orientation and direction, even its temporality and spatiality, point to the plurality of fellowship. ${ }^{40}$ The communal dimension is important even for how affect functions: Music impacts differently when it is sung by many voices; gathering together, embracing or passing the peace, all shape and provide a context for how liturgy and sacraments are experienced. These liturgical parameters and contexts obviously also need to be worked out far more fully, but this brief description provides at least some sense of the phenomenological horizon within which eucharistic experience can appear and become meaningful. ${ }^{41}$

\subsection{Liturgical Intentionality}

Third, the phenomenality of eucharistic experience, prepared and contextualized by the broader liturgical horizon, shapes a liturgical and eucharistic intentionality. Contra Marion, who wants to erase intentionality from religious phenomenality because it apparently imposes conditions, turns the recipient of revelation into a Cartesian subject constituting the phenomenon, or makes the phenomenon of revelation too predictable, intentionality is very much at stake and engaged in such experience. The liturgy forms a disposition and expectation, that is, an intentionality that prepares consciousness to intend and receive Eucharist in particular ways. We can prepare for liturgy and Eucharist, indeed, we must prepare for them, but that does not imply that we impose concepts on it arbitrarily or exercise total control over it. Such exercise of control is partly prevented through the fact that, experientially

39 Indeed, theologically speaking, this would be Manichean and deny that the world is created good.

40 Again, that is not to say that a particular person might feel out of sorts or even excluded during a rite, but to describe how the experience manifests structurally, i.e. through the parameters assumed, organized, and conveyed by the rite.

41 I have attempted to give a fuller account of how liturgical experience manifests specifically in the Eastern Orthodox tradition (Gschwandtner 2020). 
speaking, liturgy always precedes us, is often scripted for us, and is experienced as something into which we enter rather than something we manufacture. To form a dispositionality that allows for reception is not tantamount to forming a Cartesian subject in total control of the objects it encounters. ${ }^{42}$

The liturgical context shapes how consciousness becomes directed toward the phenomenon. Everything about the liturgical experience shows the importance and need for such preparation: Congregations meet at designated times, in elaborately prepared spaces, engage in complicated rituals developed and revised over long periods, often performed by carefully trained leaders, and do so over and over again, often with only slight variations. The rituals, whether sacramental or liturgical, signify precisely because of the weight of their history; a recently invented ritual means quite differently and while someone who unknowingly stumbles upon a ritual never before encountered might have an overwhelming experience, it is questionable whether it would signify in meaningful ways. Religious phenomena require preparation: physical, corporeal, mental, emotional, and spiritual. There is obviously no guarantee that the preparation will always "work"; even carefully and elaborately prepared ritual can fail. But preparation is inscribed upon the very phenomenality of liturgy, including via the aforementioned tension in which it holds anamnesis and anticipation.

To return more specifically to the Eucharist: The anaphora prayer in the liturgy of St. Basil in the Byzantine rite prays to "show" and manifest the bread as the body of Christ. ${ }^{43}$ Here we have something much closer to a phenomenological than to a metaphysical or ontological claim. The liturgical rite orients its participants toward Eucharist as body and blood of Christ; our intentionality is shaped liturgically in such a way as to receive it as body and blood of Christ. Phenomenologically speaking we might say that the point is not to explain some magical metaphysical change in the elements, but to see how everything liturgically orients us to a certain kind of reception, to shaping consciousness to enable it to receive Eucharist as the gift of Christ. This also requires preparation; it cannot happen automatically or on its own. The whole liturgy is needed in order to prepare our minds, hearts, bodies, affects, and dispositions for eucharistic participation. It is not that this piece of bread or this sip of wine suddenly gives us the sensory perception of being in first-century Jerusalem, standing by the cross-indeed, even the most literal theological interpretations do not imply such time travel or a literal re-sacrificing of Christ-but the entire hermeneutic and phenomenological horizon of liturgy shapes an intentionality that hopes for God's presence, orients itself toward the divine in contrition and veneration, forms an attitude of expectation and receptivity for the gifts. They signify, that is to say, have meaning and can be intuitively received, within that prepared and intentional horizon of liturgy.

\subsection{Phenomenological Implications}

What, then, are we to make of these very (albeit not entirely) mundane aspects of experience: eating, moving, holding, gesturing, embracing? First, this implies that Eucharist, contra Lacoste, is also (or at least) an entirely human, material, physical, sensory activity. ${ }^{44}$ Eucharist can never "mean" or "signify" without such mundane, earthy, physical dimensions. Yet, even within the ordinary, purely human, analysis of consciousness we can already detect that this experience is set apart in some form: We do not walk up to the altar in quite our usual stride, we do not simply grasp the bread but receive it from another, we usually dispense it in ornate cups or chalices set aside for special use, we bow or kneel for parts of the liturgical rite, sometimes even embrace, and we exercise all these gestures and motions in very deliberate, scripted ways. Even purely philosophically, something can, then, be "read off" from our experience here and, indeed, from how this experience is structured, what form it "usually" takes, what shape tradition has determined it "should" take (even as those traditions are plural and

42 Indeed, that is probably a caricature even of what Descartes proposes, as Marion has shown in various places.

43 Rather than praying for a transformation of the elements into body and blood of Christ, as does the liturgy of St. John Chrysostom and many Western eucharistic rites.

44 Cyril of Jerusalem already stresses this sensory element in an oft-quoted injunction for the eucharistic participants to touch their lips still wet from the Eucharist and anoint their other senses (Cyril of Jerusalem 2017, V. 22, p. 135). 
obviously undergo changes over time). ${ }^{45}$ Experience is prepared and figured in certain deliberate ways in order to produce affect, corporeal sensation, disposition. If liturgy is meant to transform us, it has to mean a transformation - though not elimination or undoing — of our ordinary human experience, of our consciousness, of our awareness, of our disposition and orientation. This is obviously not purely mental (consciousness in phenomenology is not simply about the mental), but emotional, affective, corporeal, sensorial, heart-felt, and so forth. Consciousness in the phenomenological sense is the locus of any kind of experience, not just the seat of intelligence. We are speaking here also of an experience of the heart, and of the emotions (Steinbock 2014). Eucharist appeals to and is engaged in all of them and a full account must do justice to this.

More broadly, one must also conclude that, phenomenologically speaking, religious experience is not simply a matter of overwhelming intuition imposed on us by a bedazzling phenomenon of revelation, but involves an important dimension of the shaping of dispositions and intentionality. Religious experience, at least liturgical experience and specifically eucharistic experience, emerges as a very deliberate and intentional directedness toward the phenomena, as an elaborate preparation and formation of intentionality, as the inculcation of habits and dispositions that allow for receptivity. Religious experience, liturgical experience, or eucharistic experience, does not come out of nowhere, but is meaningful precisely because we anticipate it, prepare for it, are oriented toward it, engage in it repeatedly and habitually, and do so within a community that precedes, embraces, and follows upon us. Furthermore, eucharistic experience, maybe most religious experience, is plural experience, not singular or isolated experience, as most philosophical analyses of religion have tended to imply.

This might also suggest that a way to "protect" the "mystery" of the Eucharist (as mysterion) need not take a wholly apopathic path in which the phenomenon is either so overwhelming that it cannot be perceived, as in Marion, or so kenotic that it becomes a practically empty non-experience, as in Lacoste. Nor must it be (kataphatically?) conflated with other human experiences (of eros or illness) to bring out its corporeal character, as Falque seeks to do. It is precisely the phenomenality of the broader liturgical horizon and of the intentionality that is at work within liturgical experience that hints at the manifestation of mystery: The sense that no preparation-however elaborate, beautiful, and perfectly performed -is sufficient, that no level of contrition-however groveling or transparent-will ever make us wholly "worthy" of it, that no intensity of feasting-however enthusiastic and euphoric - will ever transport us into the eschaton. Even the most carefully scripted liturgical event still maintains elements of mystery; indeed, often it is precisely this elaborate and complicated scripting that conveys the tenor of mystery and unfathomability. To say that Eucharist or liturgy are experienced always within the temporal and spatial dimensions of this world, are experienced in fully corporeal, sensorial, and affective ways, does not erase any trace of mystery, does not deny the divine transcendence invoked within it, but instead opens up the human earthly, moral, finite dimensions to them. We bring to liturgy our finitude, our vulnerability, our precarity and make of them an offering to the one we hope will heal us, feed us, console us, meet us, yet never wholly, never in such a way that we are done and need no longer return. While a purely phenomenological analysis cannot identify the divine, not name a God who becomes revealed, it can surely depict how dimensions of the mysterious mark the structures of the manifest.

All this may also help the philosopher understand more fully why ritual experience has been such an important element of human culture for most of human history-and maybe why it seeks other venues, such as sports or politics, to express itself when the religious has been abandoned or is no longer experienced as meaningful. Humans seem to need ritual, on the one hand for its signifying

45 To speak of "usually" or "general" here and above does not imply, phenomenologically, some sort of "least common denominator" or "average" of empirical experience, but instead tries to get at the character (or Wesen) of the phenomenon, the kind of phenomenon it manifests as, even when a particular empirical instance may go astray. That does not, however, turn it immediately into a normative claim about how Eucharist (or a religious phenomenon) "ought" to appear or how a rite should be structured or organized, but remains a descriptive claim. 
dimensions-it gives meaning to human experiences, marks them as important, organizes them in ways that render them significant, opens us onto mysteries that transcend our ordinary experience and yet manifest at least partially within them-and on the other for its communal dimensions-many rituals are plural and public, they elevate us beyond ourselves, allow us to participate in something larger than ourselves, give meaning that transcends one's merely personal and subjective experience. And such a phenomenological analysis may ultimately also provide methodological resources for a more explicitly theological reflection, without itself becoming dependent on theological presuppositions or assumptions. In this way, phenomenology may be of use to the theologian while remaining true to its commitment to exploring important aspects of the human condition as they manifest within human experience.

Funding: This research received no external funding.

Conflicts of Interest: The author declares no conflict of interest.

\section{References}

Alexandrescu, Vlad. 2007. Descartes and Pascal on the Eucharist. Perspective on Science 15: 434-49. [CrossRef]

Backus, Irena. 2011. Leibniz's Concept of Substance and his Reception of John Calvin's Doctrine of the Eucharist. British Journal of the History of Philosophy 19: 917-33. [CrossRef]

Cyril of Jerusalem. 2017. Lectures on the Christian Sacraments. Translated by Maxwell E. Johnson. Yonkers: St. Vladimir's Seminary Press.

Falque, Emmanuel. 2015a. This is my Body: Contribution to a Philosophy of the Eucharist. In Carnal Hermeneutics. Edited by Richard Kearney and Brian Treanor. New York: Fordham University Press.

Falque, Emmanuel. 2015b. The Wedding Feast of the Lamb: Eros, the Body, and the Eucharist. Translated by Georges Hughes. New York: Fordham University Press.

Falque, Emmanuel. 2016. Crossing the Rubicon: The Borderlands of Philosophy and Theology. Translated by Reuben Shank. New York: Fordham University Press.

Falque, Emmanuel. 2018. The Loving Struggle: Phenomenological and Theological Debates. Translated by Bradley B. Onishi, and Lucas McCracken. London: Rowman \& Littlefield.

Falque, Emmanuel. 2019. Toward an Ethics of the Spread Body. In Somatic Desire: Recovering Corporeality in Contemporary Thought. Edited by Sara Horton and et al. Lanham: Lexington.

Finn, Douglas. 2015-2016. Spiritual Consumption: Eating and the Christian Eucharist in Hegel. The Owl of Minerva 47: 109-67. [CrossRef]

Fouke, Daniel C. 1992. Metaphysics and the Eucharist in the Early Leibniz. Studia Leibnitiana 24: 145-59.

Gschwandtner, Christina M. 2014. Degrees of Givenness: On Saturation in Jean-Luc Marion. Bloomington: Indiana University Press.

Gschwandtner, Christina M. 2017. Jean-Luc Marion's Spirituality of Adoration and its Implications for a Phenomenology of Religion. In Breached Horizons: The Philosophy of Jean-Luc Marion. Edited by Steve Lofts and Antonio Calcagno. London: Rowman and Littlefield.

Gschwandtner, Christina M. 2019. What is Phenomenology of Religion? Philosophy Compass 14: e12566. [CrossRef]

Gschwandtner, Christina M. 2020. Welcoming Finitude: Toward a Phenomenology of Orthodox Liturgy. New York: Fordham University Press.

Jones, Tamsin. 2011. A Genealogy of Marion's Philosophy of Religion: Apparent Darkness. Bloomington: Indiana University Press.

Kearney, Richard, ed. 2004. Debates in Continental Philosophy: Conversations with Contemporary Thinkers. New York: Fordham University Press.

Lacoste, Jean-Yves. 2004. Experience and the Absolute: Disputed Questions on the Humanity of Man. Translated by Mark Raftery-Skeban. New York: Fordham University Press.

Lacoste, Jean-Yves. 2005. Liturgy and Coaffection. In The Experience of God: A Postmodern Response. Edited by Kevin Hart and Barbara Wall. New York: Fordham University Press.

Lacoste, Jean-Yves. 2011. Être en danger. Paris: Cerf.

Lacoste, Jean-Yves. 2015. L'intuition sacramentelle et autres essais. Paris: Ad Solem. 
Mackinlay, Shane. 2004. Eyes Wide Shut: A Response to Marion's Account of the Journey to Emmaus. Modern Theology 20: 447-56. [CrossRef]

Marion, Jean-Luc. 1991. God without Being. Translated by Thomas A. Carlson. Chicago: University of Chicago Press. Marion, Jean-Luc. 2002a. Prolegomena to Charity. Translated by Stephen E. Lewis. New York: Fordham University Press. Marion, Jean-Luc. 2002b. Being Given: Toward a Phenomenology of Givenness. Translated by Jeffrey L. Kosky. Stanford: Stanford University Press.

Marion, Jean-Luc. 2002c. In Excess: Studies of Saturated Phenomena. Translated by Robyn Horner, and Vincent Berraud. New York: Fordham University Press.

Marion, Jean-Luc. 2007. The Erotic Phenomenon. Translated by Stephen E. Lewis. Chicago: University of Chicago Press. Marion, Jean-Luc. 2008. The Visible and the Revealed. New York: Fordham University Press.

Marion, Jean-Luc. 2015. Negative Certainties. Translated by Stephen E. Lewis. Chicago: University of Chicago Press.

Marion, Jean-Luc. 2016. Givenness and Revelation. Translated by Stephen E. Lewis. Oxford: Oxford University Press, pp. 76-77.

Marion, Jean-Luc. 2017. Believing in Order to See. New York: Fordham University Press.

Sokolowski, Robert. 1994. Eucharistic Presence: A Study in the Theology of Disclosure. Washington, DC: Catholic University of America Press.

Steinbock, Anthony. 2014. Moral Emotions: Reclaiming the Evidence of the Heart. Evanston: Northwestern University Press. Wallenfang, Donald W. 2010. Sacramental Givenness: The Notion of Givenness in Husserl, Heidegger, and Marion, and Its Import for Interpreting the Phenomenality of the Eucharist. Philosophy and Theology 22: 131-54. [CrossRef]

(C) 2019 by the author. Licensee MDPI, Basel, Switzerland. This article is an open access article distributed under the terms and conditions of the Creative Commons Attribution (CC BY) license (http://creativecommons.org/licenses/by/4.0/). 